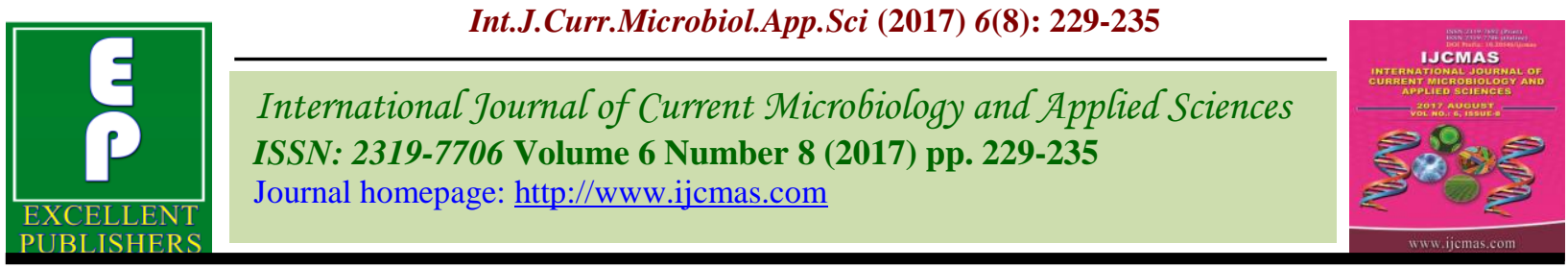

Review Article https://doi.org/10.20546/ijcmas.2017.608.031

\title{
A Multifunctional Wonder Tree: Moringa oleifera Lam Open New Dimensions in Field of Agroforestry in India
}

\author{
Yogesh Kumar ${ }^{1}$, Tarun Kumar Thakur ${ }^{1 *}$, M.L. Sahu ${ }^{2}$ and Anita Thakur ${ }^{1}$ \\ ${ }^{1}$ Department of Environmental Science, Indira Gandhi National Tribal University (IGNTU), \\ Amarkantak, Madhya Pradesh, India \\ ${ }^{2}$ Department of Forestry, Jawaharlal Neharu KrishiVishwaVidyalaya, Jabalpur, India \\ *Corresponding author
}

\section{A B S T R A C T}

\begin{tabular}{|c|c|}
\hline $\begin{array}{l}\text { Ke y w o r d s } \\
\text { Wonder tree, } \\
\text { Versatile nature, } \\
\text { Diversified } \\
\text { products, } \\
\text { Contracted and } \\
\text { Deficit. }\end{array}$ & $\begin{array}{l}\text { Moringa oliefera Lam is a wonder tree grow in all type of soil \& climate } \\
\text { especially in semiarid tropics. The tree has fast growing and drought } \\
\text { resistant in nature. The versatile nature and diversify uses of tree open new } \\
\text { dimension for fit in Agroforestry system of cropping. Beside the domestic } \\
\text { uses, ecosystem services, it's highly marked for industrial uses. The } \\
\text { industrial utility, positive interaction with crop, diversified products and }\end{array}$ \\
\hline Article Info & low management practices, enhance the value of tree at large scale. In spite \\
\hline $\begin{array}{l}\text { Accepted: } \\
\text { 04 June } 2017 \\
\text { Available Online: } \\
10 \text { August } 2017\end{array}$ & $\begin{array}{l}\text { traditional farmers in country. The contracted recognition of tree is result of } \\
\text { inadequate knowledge about the use of tree, market of its product and } \\
\text { deficit scientific approach. }\end{array}$ \\
\hline
\end{tabular}

\section{Introduction}

Moringa oleifera Lam commonly known by various name like drumstick, moringa, sahajan belongs to family Moringaceae. The name of tree varied according to its vicinity in varied province of country. Moringa is a wonder tree with its great medicinal, industrial, food, fodder, and fuel values for both human and their livestock. The origin of tree has to be believed in sub-Himalayan tracts of India, Pakistan, Bangladesh and Afghanistan (Mulugeta et al., 2014). The drought resistant, easy acquiescently in all type of soil and climate, makes it highly suitable in all parts of the world especially in semi-arid tropics. Moringa naturally found in tropical and sub-tropical forest of India or grow by farmers on bund of agricultural land. India has first rank in case of area and production of moringa. Among the Indian states, southern parts of country contribute much more in production of moringa. It is a suitable tree for traditional agroforestry in the home because of its versatility (Odee et al., 2001; Palada and Chang, 2003; Nduwayezu et al., 2007). With respect to agroforestry practices, moringa grown in home gardens, in between of agricultural crop/intercrop and on the boundaries of agricultural fields. The tree and its products are highly versatile in nature. The tree fulfills all the basic needs of human 
like food, health (medicinal properties) and wealth (by selling of its products). It is said to have known immune boosting ability (FAO, 1988; Ncube, 2006; Smith and Eyzaguirre, 2007). Every parts of tree has used in various manner by the human being. The very most utilizable parts of tree are green pod, tender leaves, flowers and seed for food purpose. With Moringa tree parts, retaining high percentages of vital nutrients throughout the year (Melesse et al., 2012). The leaves of moringa are rich source of many nutrients, vitamins and protein. Most of the products of tree are consumed by the local people itself and remaining are sold in market. The local people used the leaves and flower of moringa for vegetable purpose. They prepare a local dish called "Bhujiya" by boiling the leaves and flower of tree. The green pods are eaten in the form of various dishes like curry, soup and sambar (south Indian dish). The leaves and tender parts of tree also used as a fodder purpose. The wood produce from it are soft in nature so it is used as a fuel wood and sometime used for construction of local structures like hut, shed etc. The seed oil of moringa is edible used for cooking purpose by the local healers. Moringa seed can also be used as a water purifier both for the urban and rural inhabitants (Ali et al., 2010). During the water purifying process, seeds of moringa are tag in a piece of cloths and put in a pot where water are stored, seeds absorbed impurities and sink in to bottom of pot. Beside these direct uses the tree also have several indirect uses, it enhance the fertility of soil because each parts of tree are nutrient rich. Pod shucks and seed kernel press cake can be used as mulch and enhances soil fertility when they decompose (Prat et al., 2002). The tree are grow between crops or around the crop boost the production/productivity of crop through adding so much nutrient to agricultural field. The less lignin and chitin content in the detritus matters of tree parts make it easily decomposable, fully decomposed organic matter provide essential nutrient for growth and development of a plant Intercrops of Moringa have led to a realization of high yields in horticultural crops and its organic fertilizer has been found to be more efficient in plant growth enhancement than organic matter from other plant compost (Prat et al., 2002; Emmanuel et al., 2011). Instead of that much benefits received from this tree, are less popularized in the field of agroforestry. The present study focused the agroforestry potential of tree, its benefits to society and the technique which can make it more suitable as a one of the agroforestry component.

\section{Agroforestry potential}

Tree fulfills the entire basic prerequisite desired for as a one of the component of agroforestry system. Following are the key characteristic of tree which makes it exceedingly appropriate for agroforestry system:-

\section{Fast growing and short rotation period}

Tree has fast growing in nature and easily established, require minimum labour for planting and maintenance. The benefits obtain from tree become available to the farm family as soon as possible. Within the first year of growth, moringa has been shown to grow up to 4 meters and can bear fruit within the same first year (Folkard and Sutherland, 1996).

The tree can grow almost in all type of climate and soil, however it grow well in semi-arid tropics and sandy-loam soil.

\section{Deep root system}

Moringa has a deep tap root system with very less or few lateral roots, which will not compete for nutrients with the crops and also tree bring nutrients from deeper layer of soil to the surface. it will also added nutrients in 
field through leaf and litter fall. Tree leaves are very good as reclaiming, marginal land (Fuglie, 1999).

\section{Diversified uses}

Tree has multiple benefits to society due to it's diversify nature of products. All parts of tree are utilized in variety of purpose. The tree is known worldwide for its nutritional and medicinal benefits and industrial uses and almost every part of the plant has nutritional value (Azeez et al., 2013). Medicinal properties of tree like anti-inflammatory, curing of skin cancer, diabetes, anemia and high blood pressure. Liver, kidney, stomach and thyroid problems. Almost all parts of the tree have been utilized within traditional medicine practices (D'souza and Kulkarni, 1993). The highly medicinal properties of plant support the many pharmaceutical industries in the country. Flowers of tree is a good source of nectar for honey producing bees which support the honey industries (Adeyemi et al., 2012; Bashir et al., 2016). Moringa seed oil (yield 30-40\% w/w), also known as "Ben oil" is used for the production of biodiesel, because of the high content of monounsaturated fatty acids in the form of oleic acid (C18:1) (Azam et al., 2005; Rashid et al., 2008). Moringa seed oil is a potential candidate for biodiesel production, as it meets all the main specifications of the biodiesel standards of many countries in the world. Thus, it has great commercial and industrial importance in bio-energy sector. Beside these uses tree seed used in water purifying and the barks, gums and pulp are used for mats, printing and paper making respectively. Pod shucks and seed kernel press cake can be used as mulch and enhances soil fertility when they decompose (Prat et al., 2002). The tree has vast potential and diversify nature of its products makes it as a source of subsistence life of farmers.

\section{Food security potential}

Almost all parts of tree (leaves, flower pod for vegetable purpose seed oil for cooking purpose wood for fuel purpose) are consumed in various manners by human and their livestock. Tree has the potential of improving nutrition, boost food security, and foster rural development by enhancing and sustaining rural households as well as supporting sustainable land use and care (Adedokum et al., 2010; Odedode et al., 2010). Each products/parts of tree are rich source of vitamin and iron. Every part of the tree can be eaten especially the leaves, young shoots, young pods, flowers, roots and the bark (Adeyemi et al., 2012). Tree has long been considered a panacea for improving the nutrition of poor communities in the tropics and sub tropics (Agbogidi and Ilondu, 2012). Now a day plant are grow commercially at many parts of the world.

\section{Climate mitigate potential of tree}

All trees in nature have tangible and intangible benefits to societies. Intangible benefits include ecosystem services provide through tree or nature, essential for survival ship of human kinds. Tree improve moisture regime of soil by reducing interception losses, excess run-off and by increasing infiltration/ recharge rate and also has potential not only to arrest fast depletion of ground water table but also to reverse the trend in raising. Tree sequester aboveground and belowground carbon and thus contribute in mitigation of climate change in the long run.

According to one study, the rate of Moringa tree to absorb carbon dioxide $\left(\mathrm{CO}_{2}\right)$ is fifty times $(50 \mathrm{x})$ higher when compared to the Japanese cedar tree and also twenty times (20x) higher than that of general vegetation (Villafuerte et al., 2009). Integration of such type of tree component in agroforestry system 
prevalent in different parts of the country will mitigate the impacts of climate change. Many other ecosystem services provide tree like, Improvement of soil fertility, act as barrier for Air, Water, Soil erosion, Biodiversity and habitat conservation are very essential for equilibrium between human and nature.

\section{Economics of moringa tree}

Socio- economic consideration is very important aspects of each component in all type of farming. Unless a system is proven economical in the context of on-farm situations, it will not be adopted by the farming community. As pressure on agriculture land increased and fragmentation of farm will start very rapidly in such type of situation, poly-culture or vertical farming is the only option for subsistence of life. Rural and urban populations are becoming increasingly reliant on farm and non-farm income in order to meet their food and other needs. Products of farm trees can be important sources of farm income (Arnold et al., 1995; Ajayi et al., 2013).

As stated above, the tree has fast growing and produces in a very short duration, are a good source of income. Almost all products of tree consumed by people and their livestock remaining products are brought in market for selling. However seedlings of moringa are prepared in nursery and put on the market which fetch reasonable price and a source for generating income. The list of moringa products sold in local markets of Amarkantak region of Madhya Pradesh shown in table 1.

These products obtained from tree not only source of food to society but also generate income even in harass condition when agriculture crop has failure. So the tree has multiple benefits to society and act as source of subsistence for life of poor people.

\section{Management practices of tree in} Agroforestry field

Proper management of tree can increased the yield of agriculture crop as well as yield of tree itself. A time to time pruning, lopping and pollarding increase the yield of agricultural crop and lopping and pruning also facilitate the sprouting of leaves.

The tree Moringa oleifera open new dimension in field of agroforestry due its easily established, fast growing/ Short rotation habit, diversify nature of its products, multiple benefits to people and their livestock and several other direct and indirect benefit to societies across the world. The trees are planted between the crops or on the bund by the farmers. The yield of crop increase in the field where moringa integrated with agricultural crop because it is rich source of nutrient and withdraw the subsurface nutrient from the soil through its deep root system. Many earlier study across the world show that the growth and yield of agricultural or horticulture crop increase when this tree incorporate in field (Anjorin et al., 2010; Phiri and Mbewe, 2010; Ali et al., 2011; Yasmeen et al., 2013) crops such as wheat (Yasmeen et al., 2012 and 2013). Other than positive effect on agriculture crops, the tree has source of income to poor or small scale farmers in country.

Many country across the world where population increase at the rapid rate and agricultural land fragmentation is more common (Arnold et al., 1995; Ajayi et al., 2013). The trees are very rich source of nutrients, mineral, vitamins and protein which are essential for balance diets of human kind. In the many parts of world specially rural area where nutrient deficiency in human population are more common due to unavailability of appropriate foods, low purchasing power and improper food processing, moringa play important role in 
improving nutrition, boost food security through its highly nutrients rich products for poor people or societies lives in interiors.
(Jahn, 1988b,c; Evans, 1991; Olayemi and Alabi; Mayer and Stelz, 1993; Folkard and Sutherland, 1996; Panga, 2002).

Table.1 The list of moringa products sold in local markets of

Amarkantak region of Madhya Pradesh

\begin{tabular}{|l|l|l|}
\hline S.N. & Moringa oleifera products & Price in local market \\
\hline 1. & Leaves & 5-10 Rs./kg \\
\hline 2. & Tender pod & 20-30 Rs./kg \\
\hline 3. & Flower & 10-15 Rs./kg \\
\hline 4. & Seed & $200-300 \mathrm{Rs} . / \mathrm{kg}$ \\
\hline 5. & Fuel wood & $20-25 \mathrm{Rs} . / \mathrm{kg}$ \\
\hline
\end{tabular}

Now a day moringa tree popularized among the farmers across the world and adopted by them on their field as a tree component in agroforestry system. In recent decades moringa tree is an important component of silvo- aquaculture system due to its foliage and fruits which are very good feed for fish (Richter et al., 2003). The multiple uses and wide range of adoptability makes it as an ideal crop for sustainable food production, subsistence of life and climate resilience. These tremendous characteristic of a tree open new dimension in field of agroforestry. However there are several constraints which hamper the actual economics of these miracle trees like, lack of markets, lack of appropriate knowledge about cultivation practices, lack of planting material and Competition for land with other food crops (Mudyiwa et al., 2013). To overcome from these constraints and for boost up of the tree among the growers, a lot of research and extension activities are necessary.

The value addition of moringa raw products increased its economics and utility among the people which attract the more growers across the world. Extension activities promote the tree for further consumption to improve nutrition and medicinal functions and as well as for climate change mitigation.

\section{References}

Adedokun, M.O., Oladoye, A.O., Olawumi, A.T. and Laminou, K.I. (2010). Economic contribution of Moringa oleifera (Lam) plantation of rural livelihoods in Monoidi Local Government Area of Niger Republic. Obeche Journal, 28(2):142-146.

Adeyemi, T.O.A., Ogunrinde, C.A., Adeleke, A.S. and Omagu, J. O. (2012).Harnessing the potentials of Moringa oleifera for health improvement and poverty reductionareview. In: Onyekwelu, J.C., Agbeja, B.O., Adekunle, V.A.J., Lameed, G.A., Adesoye, R.O. and Omole, A. O. (eds.). Proceedings of the 3rd Biennial National Conference of the Forests and Forest Products Society held at University of Ibadan, April 3-6. Pp 515519

Agbogidi, O.M. and Ilondu, E.M. (2012). Effects of spent engine oil on the germination and seedling growths of Moringa oleifera (Lam). In: Onyekwelu, J.C., Agbeja, B.O., Adekunle, V.A.J., Lameed, G.A., Adesoye, R.O. and Omole, A. O. (eds.). Proceedings of the 3rd Biennial National Conference of the Forests and Forest Products Society held at 
University of Ibadan, April 3-6. Pp 336341.

Ajayi, C. A., Williams, O. A., Famuyide, O. $\mathrm{O}$ and Adebayo, O. Economic Potential Of Moringa oleifera As A Commercial Tree Species And Its Suitability For Forest Management Intervention In Taungya Farming System. Agrosearch (2013) 13 No.3: 242 - 255

Ali Z, Basra SMA, Munir H, Mahmood A, Yousaf S. 2011. Mitigation of drought stress in maize by natural and synthetic growth promoters. Journal of Agriculture, Forestry and the Social Sciences 7, 56- 62.

Anjorin TS, Ikokoh P, Okolo S. 2010. Mineral composition of Moringa oleifera leaves, pods and seeds from two regions in Abuja, Nigeria. International Journal of Agricultural and Biological Engineering 12, 431434.

Arnold, J. E. M and Dewees, P. A. (1995). Tree management in farmer strategies: responses to agricultural intensification. Oxford University Press, Oxford. 292 pp.

Azam, M. M., Waris A., Nahar, N. M. Prospects and potential of fatty acid methyl esters of some non-traditional seed oils for use as biodiesel in India. Biomass Bioenergy. 2005; 29: 293-302. doi: 10.1016/j.biombioe.2005. 05.001.

Azeez, F.A., Nosiru, M.O., Clement, N.A., Awodele, D.A., Ojo, D and Arabomen, O. Forestry Research Institute of Nigeria, P. M. B. 5054, Jericho Hill, Ibadan, Oyo State, Nigeria. Importance of Moringa oleifera tree to human livelihood: a case study of Isokan local government area in osun state. Elixir Agriculture 55 (2013) 12959-12963

Bashir, K. A., Waziri, A. F. and Musa, D. D. Moringa oleifera, A Potential Miracle Tree; A Review. IOSR-JPBS Volume 11, Issue 6 (2016). PP 25-30
D'souza, J. and Kulkarni, A.R.,(1993), Comparative studies on nutrtive values of tender foliage of seedlings and mature plants of Moringa oleifera Lam. J.Econ.Tax.Bot., 17 (2) pp479-485.

Emmanuel, S.A., Emmanuel, B.S., Zaku, S.G. and Thomas, S.A. 2011. Biodiversity and agricultural productivity enhancement in Nigeria: application of processed Moringa oleifera seeds for improved organic farming Agric. Biol. J. North America. 2 (5): 867-871.

FAO. 1988. Non timber uses of selected arid zone trees and shrubs. FAO Conservation Guide 19. FAO. Rome. pp. 92-101

Folkard, A. and Sutherland, H.O. (1996).The Moringa oleifera plant supplement of the Board Trade Journal Bulletin of the Imperial Institute Pp. 45-107

Fuglie, L. J. The Miracle Tree. Moringa oleifera: Natural Nutrition for the Tropics. Church World Service. Daka Senegal. 1999, Pp.63

Melesse, A., Steingass, H., Boguhn, J., Schollenberger, M. and Rodehutscord, M. 2012. Effects of elevation and season on nutrient composition of leaves and green pods of Moringa stenopetala and Moringa oleifera. Agroforestry Systems. 86: 505-518

Ncube, D. 2006. Moringa programmes in Binga District: 10 years of experience. Binga Trees Trust. Binga. pp. 1-4.

Nduwayezu, J.B., Chamshama, S.A.O., Mugasha, A.G., Ngaga, Y.N., Khonga, E.B. and Chabo R.G. 2007. Comparison in seed kennel sizes and early growth performance of different Moringa oleifera provenances in Southeast Botswana. Discov. Innov. 19: 52-58.

Odebode, A.V., Woes, T.O., Oyedeji, O.F., Amadi, J.O and Sowumi, I.L. (2010).Moringa oleifera: a multipurpose tree for restragetising agriculture for sustainable livelihood In: 
Akinlade, J.A., Ogunwale, A.B., Absalom, V.O, Aderinola, O.A, Ojeiyi, O.O., Rafin, T.A., Ojayeni, T.B. and Hélène, D.O. (eds.).Proceedings of the 44th Annual Conference of the Agricultural Society of Nigeria (ASN).Pp 444-445.

Odee, D.W., Muluvi, G.M., Machua, J., Olson, M.E. and Changwony, M. 2001. Domestication of Moringa Species in Kenya, Development potential for Moringa products. Workshop proceedings October 29th - November 2nd. 2001. Dar es Salaam. Tanzania.www.moringanews.org/actes/ ode e_en.doc

Palada, M.C. and Chang, L.C. 2003. Suggested cultural practices for Moringa. AVRDC. 545: 1-5

Phiri C, Mbewe DN. 2010. Influence of Moringa oleifera leaf extracts on germination and seedling survival of three common legumes. International Journal of Agricultural and Biological Engineering 12, 315-317.

Prat, J.H., Henry, E.M.T., Mbeza, H.F., Mlaka, E. and Satali, L.B. 2002. Malawi Agroforestry Extension Project Marketing and Enterprise Project Report. Agroforestry Publication No. 47. pp. 53-62

Rashid, U., Anwar, F., Moser, B. R., Knothe G. Moringa oleifera oil: a possible source of biodiesel. Bioresour Technol. 2008; 99: 8175-8179. doi: 10.1016/j.biortech.2008.03.066.
Richter N, Becker K, Siddhuraju P, 2003. Evaluation of nutritional quality of moringa (Moringa oleifera Lam.) leaves as an alternative protein source for Nile tilapia (Oreochromis niloticus L.). Aquaculture, 217(1/4)599-611.

S.M. Mudyiwa, C.T. Gadzirayi, J.F. Mupangwa, J. Gotosa and T. Nyamugure. constraints and opportunities for cultivation of Moringa oleifera in the zimbabwean smallholder growers. Int. J. Agril. Res. Innov. \& Tech. 3 (1): 12-19, June, 2013

Smith, F.I. and Eyzaguirre, P. 2007. African leafy vegetables: Their role in the world health organisation's global fruit and vegetables initiative. African J. Food Agric. Nutri. \& Dev. 7 (3): 1-17

Villafuerte LR, Villafurte-Abonal L (2009) Data taken from the Forestry Agency of Japan in Moringa. Malunggay Phillippines, Apples of Gold Publishing, Singapore, P 240.

Yasmeen A, Basra SMA, Farooq M, Rehman H, Hussain N, Athar HR. 2013. Exogenous application of moringa leaf extract modulates the antioxidant enzyme system to improve wheat performance under saline conditions. Plant Growth Regul 69, 225-233.

Yasmeen AY, Basra SMA, Wahid A. 2012. Performance of late sown wheat in response to foliar application of Moringa oleifera Lam. leaf extract. Chilean Journal of Agricultural Research 72, 92-97.

\section{How to cite this article:}

Yogesh Kumar, Tarun Kumar Thakur, M.L. Sahu and Anita Thakur. 2017. A Multifunctional Wonder Tree: Moringa oleifera Lam Open New Dimensions in Field of Agroforestry in India. Int.J.Curr.Microbiol.App.Sci. 6(8): 229-235. doi: https://doi.org/10.20546/ijcmas.2017.608.031 